\title{
IMPLEMENTASI MODEL PEMBELAJARAN DISKUSI KELAS UPAYA MENINGKATKAN MINAT PESERTA DIDIK DI KELAS VIII MTS MUHAMMADIYAH 22 PADANGSIDIMPUAN
}

\author{
Putoro Dongoran 1), Sahlan Tuah,2) \\ 1,2) FKIP Universitas Muhammadiyah Tapanuli Selatan
}

\begin{abstract}
Abstrak
Rumusan masalah dalam penelitian ini adalah kurangnya minat peserta didik terhadap mata pelajaran Pendidikan Pancasila dan Kewarganegaraan. Penelitian ini bertujuan untuk mengetahui seberapa besar implementasi model pembelajaran diskusi kelas upaya meningkatkan minat belajar mata pelajaran pendidikan pancasila dan kewarganegaraan. Jenis penelitian yang digunakan penulis adalah penelitian Asosiatif. Instrumen penelitian adalah angket. Penulis menetapkan skor tertinggi yaitu 5 dan terendah 1 . Berdasarkan analisis diatas maka diperoleh rhitung 0,835 dengan melihat daftar rtabel dengan jumlah tabel 28, selanjutnya dikonsultasikan dengan rtabel dengan taraf kesalahan yang yang ditetapkan $1 \%$ maka diperoleh harga 0,478 ternyata rhitung lebih besar dari pada rtabel yakni $0,835>0,478$, maka hipotesis alternative (Ha) dapat diterima artinya ada implementasi model pembelajaran diskusi kelas upaya meningkatkan minat belajar peserta didik di kelas VIII MTs Muhammadiyah 22 Padangsidimpuan.
\end{abstract}

Kata Kunci: Pembelajaran Diskusi Kelas, Minat Belajar

*Correspondence Address : putoro.dongoran@um-tapsel.ac.id DOI : 10.31604/jips.v6i2.2019.221-226

(C) 2019 Fakultas Keguruan \& Ilmu Pendidikan UM-Tapanuli Selatan 


\section{A. Pendahuluan}

Pendidikan adalah salah satu bentuk perwujudan kebudayaan manusia yang dinamis dan sarat perkembangan.Oleh karena itu, perubahan atas perkembangan pendidikan adalah hal yang memang seharusnya terjadi sejalan dengan perubahan budaya kehidupan. Perubahan dalam arti perbaikan pendidikan pada semua tingkat perlu terus menerus dilakukan sebagai antisipasi kepentingan masa depan guna meningkatkan kualitas pendidikan bagi peserta didik.

Ini sesuai dengan UndangUndang Nomor 20 Tahun 2003 tentang sistem Pendidikan Nasional menyatakanbahwa "Pendidikan nasional berfungsi mengembangkan kemampuan dan membentuk watak serta peradaban bangsa yang bermartabat dalam rangka mencerdaskan kehidupan bangsa.

$$
\text { Undang-undang pendidikan }
$$

sebagai salah satu dasar hukum Negara KesatuanRepublik Indonesia telah mengatur standard-standar Nasional pendidikan yang harus ditempuh oleh setiap sekolah. Yang kemudian diperjelas oleh keputusan Menteri dalam hal ini Menteri Pendidikan Nasional yang mengatur tentang perkembangan proses pembelajaran khusus mata pelajaran Pendidikan Pancasila dan Kewarganegaraan ditingkat sekolah menengah dan sederajat.

Namun, hasil di lapangan mengindikasikan, bahwa sebagian besar sekolah kurang mampu menyesuaikan diri dengan perubahan maupun perkembangan ilmupengetahuan dan teknologi, sulit untuk bisa dilatih kembali, dan kurang bisa mengembangkan diri. Indikasi tersebut menyatakan bahwa pembelajaran disekolah belum banyak menyentuh atau mengembangkan kemampuan adaptasi peserta didik.

Dengan demikian dapat disimpulkan bahwa Pendidikan Pancasila dan Kewarganegaraan merupakan salah satu ilmu dasar dan ilmu pengetahuan yang memiliki peranan penting dalam kehidupan berbangsa dan bernegara. Pendidikan Pancasila dan Kewarganegaraan merupakan bagian pendidikan secara keseluruhan dan Pendidikan Pancasila dan Kewarganegaraan mempunyai kedudukan yang sangat penting karena Pendidikan Pancasila dan Kewarganegaraan merupakan pengetahuan dasar yang berhubungan langsung dengan ilmu politik, ilmu hukum, dan ilmu kenegaraan. 
Oleh karena itu gurumendambakan agar peserta didik memiliki akhlak yang mulia, baik budi pekertinya dan berprestasi dalam semua mata pelajaran khususnya mata pelajaran Pendidikan Pancasila dan Kewarganegaraan. Semua itu dapat dilakukan melalui pendidikan yang mampu mengembangkan minat peserta didik untuk menggali potensi yang dimiliki guna masa depan yang dicita-citakan.

Minat belajar sebagai penggerak yang mendorong seseorang untuk melakukan suatu perbuatan tertentu dalam rangka mencapai tujuan yang telah ditetapkan, termasuk keikutsertaan peserta didik sangat penting karena akan menentukan keberhasilan belajar. Dengan minat belajar yang besar, maka akan meningkatkan potensi peserta didik untuk lebih tertarik dalam mempelajari Pendidikan Pancasila dan Kewarganegaraan.

Minat belajar peserta didik di kelas VIII MTs Muhammadiyah 22Padangsidimpuan terhadap mata pelajaran Pendidikan Pancasila dan Kewarganegaraan cenderung sangat lemah, dikarenakan peserta didik tidak tertarik dengan mata pelajaran tersebut dibandingkan dengan mata pelajaran lainnya. Pernyataan yang menunjukkan peserta didik lebih menyukai suatu hal dari pada hal lainnya yang dapat pula dimanifestasikan melalui partisipasi peserta didik dalam proses pembelajaran berlangsung sangat tidak efektif. Perhatian peserta didik terhadap mata pelajaran pun sangat dipengaruhi oleh persefsi peserta didik terhadap pembelajaran Pendidikan Pancasila dan Kewarganegaraan yang tidak diminati.

Menurut Oemar Muhamad AlToumi, dkk minat adalah sebagaimana Islam memelihara motivasi, kebutuhankebutuhan, keinginan-keinginan, tujuantujuan, kesediaan-kesediaan dan perbedaan-perbedaan perorangan di antara peserta didik, berusaha untuk menyiapkan peluang partisipasi dan pelaksanaan praktis diantara mereka yang menjadi tauladan bagi mereka dalam segala hal yang didakwakannya, ia juga memberi harapan kegembiraan, ketentraman, dan menjauhkan diri padanya perasaan putus asa, jengkel, kegagalan dan rasa kurang.

Menurut Usman Effendi dalam buku Ensiklopedia Pendidikan karya Instrani, "minat sangat berkaitan dengan motivasi karena manusia senantiasa menggerakkan kepada pemunahan akan kebutuhan-kebutuhan

fisiologi 
(jasmaniah), security (keamanan), hidup kemasyarakatan (sosial) dan kepuasan.

\section{Menurut Komaruddin,dkk}

"Tujuan Pendidikan Kewarganegaraan adalah mewujudkan warga negara sadar bela negara berlandaskan pemahaman politik kebangsaan, dan kepekaan mengembangkan jati diri dan moral bangsa dalam perikehidupan bangsa.

Pada saat proses belajar mengajar dilaksanakan di kelas VIII masih banyak peserta didik yang tidak memperhatikan guru dan malah berbicara dan memancing keributan, mengantuk di dalam kelas saat pembelajaran Pendidikan Pancasila dan Kewarganegaraan berlangsung dikarenakan minat belajar yang rendah terhadap mata pelajaran tersebut. Minat peserta didik dalam belajar merupakan kekuatan yang bersumber dari diri peserta didik.Dan disinilah guru memiliki peranan penting sebagai penentu kondisi pembelajaran yang diminati peserta didik.

\section{METODE PENELITIAN}

Jenis penelitian yang akan digunakan adalah penelitian kuantitatif. Penelitian kuantitatif yang dilandasi pada suatu asumsi bahwa suatu gejala itu dapat diklasifikasikan dan pengaruh gejala yang bersifat kausal (sebab akibat).

Teknik yang digunakan untuk pengumpulan data pada penelitian ini ada dua, yaituAngket yaitu bentuk pertanyaan atau pernyataan yang dibagi kepada responden untuk memperoleh data tentang minat belajar peserta didik pada mata pelajaran Pendidikan Pancasila dan Kewarganegaraan dan Model pembelajaran yang sering dibawakan guru terhadap tingkat pemahaman peserta didik.

Adapun alat pengumpulan data yang dilakukan untuk mendapat datadata penelitian ini adalah dengan angket.Penyebaran angket untuk mendapatkan data-data tentang model pembelajaran diskusi kelas dengan menggunakan instrument berbentuk skala. Selanjutnya dalam melakukan pengujian hipotesis, peneliti menggunakan rumus korelasi Product Moment menurut pendapat dari Pearson

\section{HASIL DAN PEMBAHASAN}

Berdasarkan hasil penelitian yang dilakukan, menunjukkan bahwa ada peningkatan minat belajar peserta didik menggunakan Model pembelajaran diskusi kelas terhadap minat belajar peserta didik di kelas VIIMTs 
Muhammadiyah 22 Padangsidimpuan.

Dengan rincian sebagai berikut:

Data yang diperoleh dalam pembelajaran Pendidikan Pancasila dan Kewarganegaraan peserta didik mengikutinya secara bersungguhsungguh. Hal ini dapat dilihat dari jawaban yang diberikan, yaitu yang menjawab Sangat Sering 20 orang $(71,42 \%)$, yang menjawab Sering 6 orang (21,42\%), yang menjawab Kadang-kadang 2 orang $(7,14 \%)$, yang menjawab Jarang 0 orang (0\%), dan yang menjawab tidak pernah 0 orang $(0 \%)$.

Peserta didik senang belajar Pendidikan Pancasila dan Kewarganegaraan karena mendapat nilai tinggi. Hal ini dapat dilihat dari jawaban yang diberikan, yaitu yang menjawab Sangat Sering 21 orang (75\%), yang menjawab Sering 7 orang (25\%), yang menjawab Kadang-kadang0 orang (0), yang menjawab Jarang 0 orang (0), dan yang menjawab tidak pernah 0 orang (0).

Di dalam pengujian hipotesis penelitian ini, penulis menggunakan rumus korelasi product moment dengan 2 variabel. Langkah awal yang penulis lakukan adalah dalam analisa data penelitian ini adalah dengan mencari nilai-nilai dari pada setiap variabel yang ada dalam rumus dengan menggunakan tabel koefisien korelasi product moment.

Analisa data dengan menggunakan rumus statistic product moment untuk dua variabel di peroleh hasil 0,835 . Sedangkan $r$ tabel $n=28$ pada taraf kesalahan $5 \%$ adalah 0,374 dan taraf kesalahan 1\% adalah 0,478. Dari nilai $r$ tabel tersebut dapat dilihat bahwa $r$ hitung berada di antara $r$ tabel dengan taraf kesalahan 5\% dan $1 \%$ yaitu $0,835>0,374>0,478$.

Berdasarkan analisa di atas maka dapat di simpulkan bahwa hipotesis yang penulis ajukan pada bab terdahulu dapat diterima kebenarannya. Artinya ada Implementasi Model Pembelajaran Diskusi Kelas Upaya Meningkatkan Minat Belajar Mata Pelajaran Pendidikan Pancasila Dan Kewarganegaraan Pada Materi Pokok Demokrasi Dalam Berbagai Aspek Kehidupan Peserta Didik Di Kelas VIII MTs Muhammadiyah 22 Padangsidimpuan Tahun Pelajaran 2018-2019.

Dalam perhitungan persentase, variabel X yaitu model pembelajaran diskusi kelas diperoleh rata-rata 66.54 dan variabel Y yaitu minat belajar peserta didik diperoleh rata-rata 68.18 seterusnya dilakukan analisis data dengan menggunakan rumus korelasi 
product moment, yaitu rhitung 0,835

nilai ini kemudian dibandingkan dengan

nilai rtabel dimana $\mathrm{n}=28$ orang pada taraf kesalahan $1 \%$ adalah 0,478 .

Nilai $r$ hitung lebih besar dari $r$ tabel $0,835>0,478$ hal ini menunjukkan

bahwa Implementasi Model

Pembelajaran Diskusi Kelas Upaya

Meningkatkan Minat Belajar Peserta

Didik Di Kelas VIII MTs Muhammadiyah

22 Padangsidimpuan

\section{Daftar Pustaka}

Azwar Syarifuddin. (2010). Metode Penelitian,

Yogyakarta: Pustaka Belajar.

Humalik Oemar. (2009). Metode Belajar dan Kesulitan-Kesulitan Belajar, Bandung: Tarsito.

Prasetyo Bambang. (2010). Metode Penelitian Kuantitatif, Jakarta: PT. Raja Grafindo. Rangkuti

Ahmad Nizar. (2015) Statistik Untuk Penelitian Pendidikan, Medan: Perdana Publishing

Suryanto Danang. (2010).Belajar Mudah Penelitian Untuk Guru-Karyawan dan Peneliti Pemula, Bandung: Alfabeta.

Trianto.(2009). Mendesain Model Pembelajaran Inovatif-Progresif, Jakarta: Kharisma Putra Utama.

Umar Husein. (2007). Metode Penelitian, Untuk Skripsi Tesis Bisis, Jakarta: PT. Raja Grafindo Persada.

Undang-Undang Republik Indonesia Nomor 20 Tahun 2003. Tentang Sistem Pendidikan Nasional, Jakarta.Ketentuan umum penulisan daftar pustaka: 